\title{
The impact of Integrated Crop Management technical guidance of cayenne pepper crops to the farmer's in Klungkung Regency, Bali
}

\author{
Jemmy Rinaldi ${ }^{1 *}$, Nyoman Ngurah Arya ${ }^{1}$, I Ketut Mahaputra ${ }^{1}$, Suharyanto ${ }^{2}$, Ni Wayan \\ Trisnawati ${ }^{1}$, Anella Retna Kumala Sari ${ }^{1}$, and Eko Nugroho Jati ${ }^{1}$ \\ ${ }^{1}$ Assessment Institute for Agricultural Technology (AIAT) Bali, by Pass Ngurah Rai Street, \\ Pesanggaran, South Denpasar, Denpasar City, Bali Province, Indonesia \\ ${ }^{2}$ Assessment Institute for Agricultural Technology (AIAT) Bangka Belitung Islands, Mentok Km.4 \\ Street, Pangkal Pinang, Bangka Belitung Province, Indonesia
}

\begin{abstract}
Cayenne pepper productivity in Bali Province tend to decline predicted caused by the traditionally cayenne pepper cultivation applied by farmers related. One of effort to optimize the cayenne pepper productivity is implementation of Integrated Crop Management (ICM) technology in cayenne pepper cultivation. ICM technology can be introduced to the farmers related by technical guidance method at early stage. The goal of its technical guidance method was to find out the changes of farmer's knowledge and attitude to the ICM technology of cayenne pepper cultivation. Study was conducted in Klungkung Regency used primary data obtained by directly interview using questionnaire to the 30 farmers before and after participate in the ICM technical guidance for cayenne pepper crop cultivation. Collected data was analysed by non-parametric test using Wilcoxon rank sum test. Result indicated that the farmer's knowledge significant changes to the ICM technology of cayenne pepper cultivation from not know to recognize through this technical guidance method. It was on the same line with the changes of farmer's attitude namely from hesitate became agree to the ICM component technology of cayenne pepper cultivation. This significance changes of knowledge and attitude were found out in almost all of ICM component technology.
\end{abstract}

\section{Introduction}

Cayenne pepper is one of important national horticulture commodity apart from shallot, potatoes, mango, mangosteen, orange, snake fruit, crystal guava, orchids and chrysanthemum. Cayenne pepper also has high economic value and required by almost overall citizen due to its spicy taste hold the important element in almost Indonesian cuisine. Cayenne pepper crops have been cultivated by many farmers in Indonesia including Bali. Central Statistics Agency reported that cayenne pepper's national productivity during 20072016 increased up to 3,66\% per year and it increased up to 6,28\% per year in Bali Province.

* Corresponding author: jemmy rinaldi@yahoo.com 
However, cayenne pepper's productivity in Bali decreased up to 1,67\% per year during 20172019 meanwhile the cayenne pepper's national productivity increased up to 4,60\% per year.

The decreasing of cayenne pepper's productivity in Bali may predicted caused by the technology of cayenne pepper cultivation by farmers was traditionally implemented. On other hand, the cayenne pepper's productivity able to reach up to 10-20 ton/ha supported by cayenne pepper's cultivation technology as suitable the recommendation [1]. The traditional farming system is characterized by pest and disease management was done by using chemical pesticide intensively without considering the Integrated Pest Management (IPM) principals. Excessive use of chemical pesticide created many negative effects such as the increasing of farming system cost, un-optimum crops productivity, environmental pollution, the presence of pesticide residues in fruits or vegetables after and during harvest, pest become resistant to pesticides, the destruction of biodiversity, lead to secondary pest outbreaks and harmful to human health $[2,3,4,5,6,7]$. Furthermore, farmers in Bali Province have not applicated yet the balanced fertilization, they only applicated the chemical fertilizer for their farming system. Anisyah [8] stated that the use of chemical fertilizer without combined with the organic fertilizer can lead to the lack of soil fertility. Organic fertilizer hold important role to improve phsyic, chemical and biological soil properties. Organic fertilizer capable to increase soil fertility and crops productivity. The application of organic fertilizer has potential to reduce the dependency of chemical fertilizer [9].

One of efforts to solve issues described above are the implementation of Integrated Crop Management (ICM) technology for cayenne pepper crops cultivation. The Integrated Crop Management (ICM) is a farming method that balances the requirements of running a profitable business with environmentally sustainable responsibility includes waste management practices, enhance energy efficiency and minimize pollution. The ICM technology linked to best management practices such as Integrated Pest Management (IPM) includes soil fertility, the timing of planting and harvesting, varieties selection, tillage, crop rotations, the uses of silver-on-black plastic mulch and other crop production factors. All crop production management decisions were created by considering the balance of labor availability, soil, machinery resources and environmental concern. ICM combines the traditional farming methods with appropriate modern technology also good environmental management. The ICM implementation is emphasizing on farmer active participation to choose and evaluate appropriate technology for their biophysical environment, socialcultural, and economic aspect. The implementation of ICM is not only solely purposed to maximizing yields but also environmentally sustainable while increasing production efficiency and profitability [7, 11, 10, 12]. Many studies have reported the successful of ICM implementation to increase the productivity of crops and farmer's income particularly to the food crops and horticulture commodity such as rice, maize, and cayenne pepper $[13,14,15$, $16,17,18]$.

The dissemination of ICM technology for cayenne pepper crops cultivation is necessary to be transferred to the farmers in order to change the farmer's habits and attitudes in cayenne pepper crops cultivation. Furthermore, it can be realized by doing the ICM technical guidance of cayenne pepper crops to the farmers. Study by [19] proved that technical guidance capable to improve the knowledge and attitude's stakeholder as the active user of technology innovation in the future. The goals of this study were (1) to find out the changes of farmer's knowledge to the ICM technology of cayenne pepper cultivation, (2) to find out the change of farmer's attitude to the ICM technology of cayenne pepper cultivation.

\section{Materials and methods}

Research location was selected purposively namely in Subak Kacang Dawa, Gelgel Village, Klungkung District, Klungkung Regency, Bali Province according to the declaration of this 
area as centre for horticulture commodity development area particularly cayenne pepper in Bali Province. Study was conducted in April 2020 used primary data obtained by directly interview using questionnaire to the 30 farmers before and after participate in the ICM technical guidance for cayenne pepper crop cultivation.

Questionnaire was arranged consist of ICM component technology particularly related to the farmer's attitude and knowledge to the ICM technology for cayenne pepper crops cultivation such as the utilization of superior varieties, seed treatments, seed nursery, the utilization of Mirabilis jalapa extract to induce the plant resistance to virus pathogen, ideal seedbeds preparation for optimum yield, the use of silver-on-black plastic mulch, the uses of organic fertilizer, the uses of NPK fertilizer as basic fertilizer, dolomite application to acidic soils, the uses of cover, border and trap crops to repel insect herbivores on crop plants, the ideal plant spacing, irrigation, fertilization, stake installation, pruning of lateral shoots, the uses of organic pesticide, application of yellow sticky trap to trap many pests and harvesting crops at the right time.

Collected data was analysed by non-parametric test using Wilcoxon rank sum test to know the significance differences in each ICM component technology questioned to the farmers based on their knowledge and attitude. Data obtained was also analysed the average of its changes according to the classification which determined by using interval equation [20]:

Note:

$$
I=\frac{J}{K}
$$

I $\quad=$ Class interval

$J \quad=$ The space between maximum score and minimum score

$K \quad=$ number of class used in grouping

The measurement of each ICM technology components based on five classifications in farmer's knowledge and atttitude which described in Table 1.

Table 1. The classification measurement of farmer's knowledge and attitude to the ICM technology for cayenne pepper crops cultivation

\begin{tabular}{|ll|ll|}
\hline \multicolumn{2}{|l|}{ Knowledge classification } & \multicolumn{2}{c|}{ Attitude classification } \\
\hline$\bullet$ & Fully not understand & $\bullet$ & Strongly disagree \\
\hline$\bullet$ & Not understand & $\bullet$ & Disagree \\
\hline$\bullet$ & Enough understand & $\bullet$ & Hesitant \\
\hline$\bullet$ & Understand & $\bullet$ & Agree \\
\hline$\bullet$ & Fully understand & Strongly agree \\
\hline
\end{tabular}

\section{Result and discussion}

\subsection{The changes of farmer's knowledge to the cayenne pepper's ICM technology}

Knowledge is the initial stage in the occurrence of perception then forms attitudes and creates actions. Sudarta [21] argued that knowledge had important meaning in terms of accelerating agricultural development due to knowledge capable to improve the ability to adopt new agricultural technology. The farmer's knowledge in Subak Kacang Dawa, Gelgel Village, Klungkung District, Klungkung Regency at pre and post of the ICM technology technical guidance can been seen in Table 2 .

The average of farmer's knowledge at pre-the ICM technology technical guidance in Subak Kacang Dawa, Gelgel Village, Klungkung District, Klungkung Regency reached the score was 2,21 therefore it can be said that the farmers were not understand the ICM 
technology for cayenne pepper cultivation (Table 2). This score proved that farmers related conducted their traditionally cayenne pepper farming system during this time. Meanwhile at the post-the ICM technology technical guidance, the farmers knowledge was increase to higher category namely understand strengthen by the changes of score average reached 3,48 (Table 2). It can be concluded that the ICM technical guidance had ability to improve the farmer's knowledge about good practices in terms of cayenne pepper cultivation.

Table 2. The farmer's knowledge at pre and post of the Integrated Crop Management (ICM) technical guidance for cayenne pepper cultivation in Subak Kacang Dawa, Gelgel Village, Klungkung District, Klungkung Regency in 2020

\begin{tabular}{|c|c|c|c|c|c|}
\hline \multirow{2}{*}{ ICM components } & \multicolumn{2}{|c|}{ Score of knowledge } & \multicolumn{3}{c|}{ Changes (person) } \\
\cline { 2 - 6 } & Pre- & Post- & $\begin{array}{c}\text { Positiv } \\
\text { e }\end{array}$ & $\begin{array}{c}\text { Negativ } \\
\text { e }\end{array}$ & $\begin{array}{c}\text { Tie } \\
\text { s }\end{array}$ \\
\hline Superior varieties & $1.63 \mathrm{a}$ & $3.90 \mathrm{~b}$ & 27 & - & 3 \\
\hline Seed treatment & $2.00 \mathrm{a}$ & $3.50 \mathrm{~b}$ & 23 & - & 7 \\
\hline Seed nursery & $1.70 \mathrm{a}$ & $3.17 \mathrm{~b}$ & 24 & - & 6 \\
\hline Organic inducers for plant resistance & $1.37 \mathrm{a}$ & $3.10 \mathrm{~b}$ & 25 & - & 5 \\
\hline Ideal seedbeds preparation & $3.73 \mathrm{a}$ & $4.10 \mathrm{~b}$ & 14 & - & 16 \\
\hline Silver-on-black plastic mulch & $2.83 \mathrm{a}$ & $3.40 \mathrm{~b}$ & 15 & - & 15 \\
\hline Organic fertilizer & $2.27 \mathrm{a}$ & $3.93 \mathrm{~b}$ & 28 & - & 2 \\
\hline NPK fertilizer as basic fertilization & $2.83 \mathrm{a}$ & $3.93 \mathrm{~b}$ & 22 & - & 8 \\
\hline Dolomite fertilizer & $1.57 \mathrm{a}$ & $3.37 \mathrm{~b}$ & 27 & - & 3 \\
\hline Cover, border and trap crops & $2.00 \mathrm{a}$ & $3.33 \mathrm{~b}$ & 24 & - & 6 \\
\hline Seed plantation & $1.53 \mathrm{a}$ & $2.93 \mathrm{~b}$ & 24 & - & 6 \\
\hline Plant spacing & $2.77 \mathrm{a}$ & $3.93 \mathrm{~b}$ & 24 & - & 6 \\
\hline Irrigation & $3.37 \mathrm{a}$ & $4.03 \mathrm{~b}$ & 18 & - & 12 \\
\hline Fertilization & $2.00 \mathrm{a}$ & $3.43 \mathrm{~b}$ & 21 & - & 9 \\
\hline Stake installation & $1.83 \mathrm{a}$ & $3.07 \mathrm{~b}$ & 22 & - & 8 \\
\hline Pruning of lateral shoots & $1.87 \mathrm{a}$ & $2.17 \mathrm{a}$ & 12 & - & 18 \\
\hline Organic pesticide & $1.80 \mathrm{a}$ & $3.43 \mathrm{~b}$ & 27 & - & 3 \\
\hline Yellow sticky traps & $1.60 \mathrm{a}$ & $3.47 \mathrm{~b}$ & 27 & - & 3 \\
\hline Harvesting at right time & $3.20 \mathrm{a}$ & $3.87 \mathrm{~b}$ & 20 & - & 10 \\
\hline Average & 2.21 & 3.48 & & & \\
\hline & Not & & & & \\
\hline Category & understan & Understan & & & \\
\hline
\end{tabular}

Note: Numbers followed by the different letters in the same column were significantly different according to Wilcoxon rank sum test $(\mathrm{P}<0.05)$

Knowledge classification: Fully not understand (1.00-1.79), not understand (1.80-2.59), enough understand (2.60-3.39), understand (3.40-4.19), fully understand (4.20-5.00)

Most of the farmer's knowledge changes about the ICM technology components were significantly changing into positive direction except pruning of lateral shoots. Even though the pruning of lateral shoots was positively changed, it was not significantly different to pretechnical guidance. It caused by the distrust in farmers to pruning of lateral shoots. Farmers thought that pruning of lateral shoots would obstruct the plant growth. The pruning of lateral shoots aimed to optimize the plant growth by removing many of the flower buds and lateral buds to promote main branching. Pruning will make the fruits easier to harvest (height and position of fruit), have larger and higher quality fruit, likely more disease free and have improved structural support for the fruit [22]. The largest of farmer's knowledge changing occurred on technology component of organic fertilizer utilization, superior varieties, dolomite fertilizer, organic pesticide, yellow sticky traps, organic inducers for plant resistance, seed nursery and seed treatment. 
The farmer's knowledge about the utilization of organic fertilizer for cayenne pepper cultivation was significantly increase to higher category namely from not understand (2.27) became understand (3.93). It means that farmers have understood the important of organic fertilizer utilization for cayenne pepper cultivation through the ICM technology technical guidance. Before this technical guidance, farmers know nothing about the important of organic fertilizer for their farming system therefore they did not apply the organic fertilizer during this time. Study by [23] reported that the utilization of organic fertilizer in cayenne pepper crops significantly affected to vegetative and generative phase growth also its productivity. In line with these statements, organic fertilizer positively affected to plant height, numbers of productive branches, and number of fruits per plant and fruits weight per plant [24]. The application of manure fertilizer from cattle, goat and chicken improved the growth and yield crops particularly plant height, branching level, fruits length and dried weight stover [25].

The significantly increasing of farmer's knowledge also occurred in superior variety utilization technology component namely from fully not understand (1.63) became understand (3.90). It indicated that farmers understand the important of superior variety utilization through this technical guidance. The implementation of superior variety utilization technology which suitable to land characteristics would impact to better yield compared to the utilization of seeds from previous harvest. Most farmers did not know the presence of superior cayenne pepper variety therefore they always use local cayenne pepper variety [26].

The changes of farmer's knowledge also can be found in dolomite fertilizer utilization technology component namely significantly changing into positive direction from fully not understand classification (1.57) became understand classification (3.37). It means that farmers have understood the important of dolomite fertilizer utilization for cayenne pepper cultivation through the ICM technology technical guidance. It happened due to farmers never measure the soil acidity in their cayenne pepper cultivation. Dolomite fertilizer utilization can improve the physic, chemical and biological soil properties therefore it can enhance the efficiency of nutrient absorption from organic and chemical fertilizer [27]. Study by [28] showed that dolomite fertilizer utilization for cayenne pepper cultivation in inceptisol and peat soil greatly affected to stem diameter, number of fruits, fruits length, fruits diameter and fruit weight.

Other changes of farmer's knowledge also happened in organic pesticide utilization technology component. The changes mentioned was from not understand (1.80) became significantly change to understand (3.43). It proved that farmers have understood the important of organic pesticide utilization for cayenne pepper cultivation through the ICM technology technical guidance to control the pest and disease against and minimize the cost of farming system for purchasing the chemical pesticide. Study by [4] reported that the organic pesticide utilization to control the pest and disease against able to suppress the chemical pesticide utilization up to $73.33 \%$ and also decrease the cost of chemical pesticide purchase up to $96.39 \%$. Organic pesticide can reduce the intensity level of anthracnose in cayenne pepper crops [29]. As same as with organic pesticide utilization, farmer's knowledge about the utilization of yellow sticky traps also positively and significantly changes from fully not understand (1.60) became understand (3.47). Farmers never tried to do preventive action of pest and disease against in cayenne pepper crops. Ladja [30] stated that yellow colour in yellow sticky traps attract the herbivorous insect pest, captured them and then reduced their migration on host crops.

Farmer's knowledge about organic inducers for plant resistance particularly inducers made from Mirabilis jalapa extract was also greatly improve namely from fully not understand category (1.37) change to enough understand (3.10). Through ICM technology technical guidance, farmers quite understand the important of organic inducers application for plant resistance to virus pathogen against in cayenne pepper crops. Farmers also obtain 
the knowledge about how to make these inducers. Farmers never tried to do preventive action of virus pathogen against which cause curl and bright yellowing leaf in cayenne pepper crops which caused the reducing of yield. Study by Reference [31] reported that Mirabilis jalapa flower extract has ability to suppress the virus pathogen attack in cayenne pepper crops.

In terms of seed treatment and seed nursery, farmer's knowledge also significantly improved from not fully understand (1.70) became quite understand (3.17) for seed nursery. Meanwhile for seed treatment, the change was from not understand category (2.00) became understand category (3.50). Seed treatment by hot water soaking can prevent establishment of seed-borne diseases on the farm [32]. This statement also strengthened by [33,34] that seed treatment by using Rhizobacteria capable to control and suppress the disease incidence by fungus Phytophthora capsici in cayenne pepper crops. During this time, farmers are used to directly planting the seed into land been prepared without seed treatment and nursery first. These habits cause the large seed requirement for their farming system due to it require 6-10 seeds per hole.

Farmer's knowledge was one of key factor which determined the farmer's ability to adopt new technology in their farming system [21]. The higher farmer's knowledge level, their ability to adopt new technology will be higher. With the increase in farmers' knowledge, the dissemination of cayenne pepper's ICM technology can be transferred quickly to the farmers.

\subsection{The changes of farmer's attitude to the cayenne pepper's ICM technology}

In generative phase, parameters observed were 5 fruits weight, fruit length and fruit diameter. Attitude is defined as the degree of human's depressing or encouraging feeling and mirrored the way of thinking, feeling or acting of a person towards a situation or cause. Attitude of an individual hold an important role in determining behaviour [35]. Reference [36] said that attitude indicated the readiness of farmers to react on adopting the appropriate technology. Attitude also is one of key factor considering in term of farmer's adopting level. The changes of farmer's attitude to the Cayenne Pepper's ICM technology at Subak Kacang Dawa, Gelgel Village, Klungkung District, Klungkung Regency were informed in Table 3. 
Table 3. The farmer's attitude at pre and post of the Integrated Crop Management (ICM) technical guidance for cayenne pepper cultivation in Subak Kacang Dawa, Gelgel Village, Klungkung District,

Klungkung Regency in 2020

\begin{tabular}{|c|c|c|c|c|c|}
\hline \multirow{2}{*}{ ICM components } & \multicolumn{2}{|c|}{ Score of knowledge } & \multicolumn{3}{c|}{ Changes (person) } \\
\cline { 2 - 5 } & Pre- & Post- & Positive & Negative & Ties \\
\hline Superior varieties & $2.70 \mathrm{a}$ & $4.20 \mathrm{~b}$ & 21 & - & 9 \\
\hline Seed treatment & $2.77 \mathrm{a}$ & $4.20 \mathrm{~b}$ & 21 & - & 9 \\
\hline Seed nursery & $2.20 \mathrm{a}$ & $3.57 \mathrm{~b}$ & 26 & - & 4 \\
\hline Organic inducers for plant resistance & $2.23 \mathrm{a}$ & $3.60 \mathrm{~b}$ & 25 & - & 5 \\
\hline Ideal seedbeds preparation & $3.80 \mathrm{a}$ & $4.37 \mathrm{~b}$ & 15 & - & 15 \\
\hline Silver-on-black plastic mulch & $2.63 \mathrm{a}$ & $3.93 \mathrm{~b}$ & 22 & - & 8 \\
\hline Organic fertilizer & $2.77 \mathrm{a}$ & $4.07 \mathrm{~b}$ & 19 & - & 11 \\
\hline NPK fertilizer as basic fertilization & $3.40 \mathrm{a}$ & $4.27 \mathrm{~b}$ & 18 & - & 12 \\
\hline Dolomite fertilizer & $2.83 \mathrm{a}$ & $3.87 \mathrm{~b}$ & 20 & - & 10 \\
\hline Cover, border and trap crops & $2.67 \mathrm{a}$ & $3.83 \mathrm{~b}$ & 23 & - & 7 \\
\hline Seed plantation & $2.13 \mathrm{a}$ & $3.60 \mathrm{~b}$ & 24 & - & 6 \\
\hline Plant spacing & $2.93 \mathrm{a}$ & $4.33 \mathrm{~b}$ & 20 & - & 10 \\
\hline Irrigation & $3.63 \mathrm{a}$ & $4.27 \mathrm{~b}$ & 17 & - & 13 \\
\hline Fertilization & $2.97 \mathrm{a}$ & $3.77 \mathrm{~b}$ & 17 & - & 13 \\
\hline Stake installation & $2.07 \mathrm{a}$ & $3.80 \mathrm{~b}$ & 26 & - & 4 \\
\hline Pruning of lateral shoots & $2.30 \mathrm{a}$ & $3.00 \mathrm{~b}$ & 18 & - & 12 \\
\hline Organic pesticide & $3.00 \mathrm{a}$ & $3.97 \mathrm{~b}$ & 19 & - & 11 \\
\hline Yellow sticky traps & $2.40 \mathrm{a}$ & $3.90 \mathrm{~b}$ & 24 & - & 6 \\
\hline Harvesting at right time & $3.33 \mathrm{a}$ & $4.13 \mathrm{~b}$ & 14 & - & 16 \\
\hline Average & 3.02 & 3.93 & & & \\
\hline Category & Hesitant & Agree & & & \\
\hline
\end{tabular}

Note: Numbers followed by the different letters in the same column were significantly different according to Wilcoxon rank sum test $(\mathrm{P}<0.05)$

Knowledge classification:

- Strongly disagree (1.00-1.79)

- Disagree (1.80-2.59)

- Hesitant (2.60-3.39)

- Agree (3.40-4.19)

- Strongly agree (4.20-5.00)

It can be seen on the Table 3 that the average of farmer's attitude at pre-the ICM technical guidance for cayenne pepper crops cultivation at Subak Kacang Dawa, Gelgel Village, Klungkung District, Klungkung Regency obtain score was 3.02 and categorized into hesitant classification to the ICM technology for improve their cayenne pepper crop cultivation. The change was occurred after they obtained the information about ICM component technology through technical guidance. The change mentioned was their score was increase up to 3.93 which mean that they agree with ICM technology component. It was encouraging to understand that the ICM technology technical guidance for cayenne pepper crops cultivation capable to improve the farmer's attitude namely being agree to the implementation of ICM technology to obtain optimum yield in their cayenne pepper crops cultivation. Based on Wilcoxon sum rank test, all the farmer's attitude changes about the ICM technology components were significantly changing into positive direction. The largest farmer's attitude changes can be found at ICM component technology of seed nursery, stake installation, organic inducers for plant resistance, seed plantation, the utilization of yellow sticky traps, border crops and silver-on-black plastic mulch.

Farmer's reaction to the seed nursery technology component at pre and post of the ICM technical guidance were significantly and positively different each other namely from 
disagree (2.20) being agree (3.57). It indicated farmers agree that seed nursery can bring great effect on the cayenne pepper growth rather than directly planting into the soil. The same pattern also occurred in stake installation technology component which the score obtained were 2.07 (disagree) at pre- and 3.80 (agree) at post-. This technical guidance can open up farmer's mind to be agree the stake installation for their cayenne pepper crops cultivation. During this time, farmers never implemented the stake installation. It is important to be known by farmers that the stake installation can prevent the crops and fruits from falling down, stake installation can help the cayenne pepper crops handle their own weight when produce bountiful harvest [22].

At pre of the ICM technical guidance, farmers tend to disagree to the ICM technology component of organic inducers for plant resistance, seed plantation and the utilization of yellow sticky traps. The ICM technical guidance capable to initiate the dissemination of ICM technology information to the farmers therefore they believe and agree that implementation of organic inducers for plant resistance, seed plantation and yellow sticky traps have positive beneficial for their farming system. Study by [31] demonstrated that organic inducers made from Mirabilis jalapa flower extract can suppress the curl and bright yellowing leaf incidence in cayenne pepper crops. Mirabilis jalapa flower extract contained saponin and flavonoid which able to induce the systemic resistance of cayenne pepper crops to the virus pathogen attacks [37]. Mirabilis jalapa flower extract also have been reported its ability to control pathogen attacks on the yard long beans which characterized by the increasing of fresh pods yard long beans weight, fresh and dried stover weight [38]. Farmers also agree that seed planting by one seed per hole create nothing competition in terms of nutrients absorption by crops and can enhance the efficiency of seed utilization. Through this technical guidance, farmers also approve that the uses of yellow sticky traps can repel the existence of herbivorous insect pests to migrate on crops. Yellow sticky traps can trap the thrips, aphids, fruit flies and others [39].

For the uses of cover, border, trap crops and silver-on-black plastic mulch, the farmer's attitude changes were from hesitant became agree which the score were 2.67 and 2.63 (pre-) respectively and 3.83 and 3.93 (post-) respectively. Farmers believe that the uses of cover, border and trap crops in order to reduce the presence of herbivorous insect pests on crops. Farmers agree that silver-on-black plastic mulch capable to maintain the soil moisture and minimize the pest population on under the leaves. This is in line with the results of research by Reference [40] which stated that silver colour will reflect sunlight therefore groundwater evaporates less and pests are reluctant to presence because of glare and can prevent crops from attack by under-leaves pests such as aphids, mites, trips, caterpillars and others. The utilization of silver-on black plastic mulch in cayenne pepper crops was more effective in controlling the Myzus persicae population as major pest rather than black plastic mulch [41]. Other studies also have been reported that silver-on black plastic utilization showed the better growth and yield crops particularly compared to the straw mulch and without mulch treatment due to it produce the higher number of fruits and total production [42, 43, 44, 45].

Based on results obtained in this study, it can be predicted that farmers tend to interest to adopt the cayenne pepper's ICM technology. Results also indicated that correlation between farmer's attitude and the decision to adopt appropriate technology strongly influenced by internal factors such as farming system experience and external factors such as the land suitability, the easiness of farming system, the availability of infrastructure and farmers group supporting [36]. 


\section{Conclusion and recommendation}

The ICM technology technical guidance capable to improve the farmer's knowledge and attitude to the ICM technology for cayenne pepper crops cultivation. The improved mentioned was significantly different namely from not understand category became understand category and from hesitant classification improve to agree classification.

Related government is expected to conduct the ICM technology technical guidance to overall farmers in Bali Province particularly in Klungkung Regency as the centre for horticulture commodity development area. It is necessary to build the demonstration plot for cayenne pepper crops cultivation using ICM technology as learning media for farmers.

Acknowledgement. We would like to thank Bali Assessment Institute for Agricultural Technology for funding this research.

Author contribution statement. All authors were main contributors in research implementation and creating the manuscript. Jemmy Rinaldi as people in charge of this research. I Ketut Mahaputra as field coordinator and Nyoman Ngurah Arya as co-field coordinator during research implementation. Ni Wayan Trisnawati and Suharyanto contribute to help the tasks of people in charge of this research. Anella Retna Kumala Sari and Eko Nugroho Jati contribute to the creating research design, research implementation, data collecting, data analysis, drafting the manuscript until officially published.

\section{References}

1. Direktur Jenderal Bina Produksi Hortikultura. Statistik Hortikultura tahun 2010. Dirjen Hortikultura, Departemen Pertanian, Jakarta 125 hal. (2010)

2. A. F. Abang, C. M. Kouame, M. Abang, R. Hannah and A. K. Fotso. International Journal of Agronomy and Plant Production, 4, 5 (2013).

3. K. S. Akutse, S. Subramanian, N. K. Maniania, T. Dubois, and S. Ekesi. Frontiers in Sustainable Food Systems, 4, (2020).

4. A. Hasyim, W. Setiawati and L. Lukman. Jurnal Pengembangan Inovasi Pertanian, 8, 1 (2015).

5. A. Hasyim, W. Setiawati, L. S. Marhaeni, L. Lukman and A. Hudayya. J Hort, 27, 2 (2017).

6. Supriadi. J. Litbang Pertanian, 32, 1 (2013).

7. A. Wihardjaka and D. Nursyamsi. Pangan, 21, 2 (2012).

8. F. Anisyah, Sipayung, R., Hanum, C. J. Online Agroekoteknologi, 2, 2 (2014).

9. W. Hartatik and D. Setyorini. Pemanfaatan pupuk organik untuk meningkatkan kesuburan tanah dan kualitas tanaman. Balai Penelitian Tanah. Bogor. Badan Litbang Pertanian. http://balittanah.litbang.pertanian.go.id. Diunduh pada tanggal 3 Mei 2021. (2012)

10. E.T. Pasetriyani. Jurnal Agribisnis dan Pengembangan Wilayah, 2, 1 (2010).

11. Sudiono, S. H. Sutjahjo, N. Wijayanto, P. Hidayat, and R. Kurniawan. J. Hort, 27, 2 (2017).

12. S. Swastika, D. Pratama, T. Hidayat and K. B. Andri. Teknologi Budidaya Bawang Merah. Petunjuk Teknis. Balai Pengkajian Teknologi Pertanian Riau. Badan Penelitian dan Pengembangan Pertanian. Kementerian Pertanian. Jakarta. (2017)

13. A. Supriyo, Y. Hindarwati, and R. Nurlaily. Jurnal Ilmu Lingkungan, 18, 1 (2020).

14. E. Iskandar, B. Sawitri, and Suryani. Journal of Extension and Development, 2, 1 (2020).

15. H.M. Kholid. Magister Agribisnis, 18, 2 (2018).

16. P.Y. Silitonga, S. Hartoyo, B.M. Sinaga, and I.W. Rusastra. Informatika Pertanian, 25, 2 (2016). 
17. S.L. Margaretha, and Syuryawati. Jurnal Penelitian Pertanian Tanaman Pangan, 1, 1 (2017).

18. Sutardi, and C.A. Wirasti. Jurnal Pengkajian dan Pengembangan Teknologi Pertanian, 20, 2 (2017).

19. Risna, H.S.P. Rahayu, and B.S.L. Ishak. Peningkatan Pengetahuan Penyuluh Terhadap Teknologi Tumpangsari Tanaman Melalui Bimbingan Teknis di Sulawesi Tengah. Prosiding Seminar Nasional Teknologi Pertanian "Kesiapan Sumber Daya Pertanian dan Inovasi Spesifik Lokasi Memasuki Era Industri 4.0”, ISBN : 978-602-6954-39-8, hal : 436-443. (2019)

20. A. Dajan. Pengantar Metode Statistik, Jilid Kedua. LP3ES. Jakarta. (1996)

21. W. Sudarta. Jurnal Sosial Ekonomi Pertanian dan Agribisnis, 2, 1 (2002).

22. Balai Pengkajian Teknologi Pertanian (BPTP) Jawa Tengah. Budidaya dan Pasca Penen Cabai Merah, Cetakan I. Balai Pengkajian Teknologi Pertanian Jawa Tengah. Badan Penelitian dan Pengembangan Pertanian. (2010)

23. S. Imas, Damhuri and A. Munir. Jurnal Ampibi, 2, 1 (2017).

24. E. Nurahmi, T. Mahmud and S. S. Rosiana. Jurnal Floratek, 6, (2011).

25. M. Wijayanti, M.S. Hadi and E. Pramono. Jurnal Agrotek Tropika, 1, 2 (2013).

26. N. Minanti, W. Aradiana and W. Nasruddin. Jurnal Inovasi Peneltian, 1, 4 (2020).

27. I. Juarsah. Jurnal Agro, 3, 1 (2016).

28. E.M. Janah, Idwar and Armaini. Jurnal Dinamika Pertanian, 26, 1 (2020).

29. S. Zulkipli, Y. Marsuni and H.O. Rosa. Jurnal Proteksi Tanaman Tropika, 1, 2 (2018).

30. M.G. Ladja, I. Hindun, Sukarsono, R.E Susetyarini and D. Setyawan. Pengendalian Lalat Buah (Bactrocera sp) Secara Biologi Menggunakan Attractant dan Warna pada Tanaman Jambu Biji (Psidium guajava). Prosiding Seminar nasional IV 2018 "Peran Biologi dan Pendidikan Biologi dalam Revolusi 4.0 dan Mendukung Pencapaian Sustainability Development Goals (SDG's), ISBN : 978-602-5699-43-6, hal : 246-250. Universitas Muhammadiyah Malang. (2018)

31. S.M. Prabowo and S.A. Dewi. Jurnal Kultivasi, 18, 2 (2019).

32. Y. Marsuni. Pencegahan Penyakit Antraknosa pada Cabai Besar (Lokal: Lombok Ganal) dengan Perlakuan Bibit Kombinasi Fungisida Nabati. Prosiding Seminar Nasional Lingkungan Lahan Basah, Vol. 5, No. 2, April 2020 : 113-116. Universitas Lambung Mangkurat. (2020)

33. A. Ibrahim, S. Ilyas and D. Manohara. Buletin Agrohorti, 2, 1 (2014).

34. F.N. Rosadiah, S. Ilyas and D. Manohara. Jurnal Hortikultura Indonesia, 6, 1 (2015).

35. W.S. Winkel. Psikologi Pengajaran. Jakarta: Gramedia. (1987)

36. E.T. Yuniarsih, A.N. Tenriawan, S. Haerani andA. Syam. Jurnal Pengkajian dan Pengembangan Teknologi Pertanian, 23, 3 (2020).

37. W. Setiawati. Modul Pelatihan SL-PTT Cabai Merah - Bawang Merah. Pusat Penelitian dan Pengembangan Hortikultura, Badan Penelitian dan Pengembangan Pertanian, Kementerian Pertanian. Jakarta. (2010)

38. Supyani, S. Widadi and W. H. A. Jamil. Agrotechnology Research Journal, 1, 1 (2017).

39. E. Firmansyah and S. Nurhidayah. Journal of Empowerment Community, 1, 1 (2019).

40. Murnita, L. Hermalena. Aplikasi Mulsa Plastik Hitam Perak (MPHP) pada Budidaya Tanaman Cabai Keriting. The 2nd Seminar Nasional APDI Mengabdi untuk negeri Pengabdan Masyarakat di Era New Normal. Prosiding Vol. 2, No. 2 (2021) ISSN: 27461246, hal: 312-317. (2021)

41. K.D. Utama, I G.N. Bagus, I K. Siadi, I D.N. Nyana and G. Suastika. E-Jurnal Agroekoteknologi Tropika, 4, 1 (2015).

42. S. Ardhona, K. Hendarto, A. Karyanto dan Y. C. Ginting. Jurnal Agrotek Tropika, 1, (2013). 
43. A. Aditya, K. Hendarto, D. Pangaribuan, K.F. Hidayat. Jurnal Agrotek Tropika, 1, 2 (2013).

44. I G.P. Darmawan, I D.N. Nyana dan I G.A. Gunadi. E-Jurnal Agroekoteknologi Tropika, 3, 3 (2014).

45. Z. Sahrain, N. Musa and W. Pembengo. Jurnal JATT. 7, 3 (2018). 